\title{
The Case of Gorizia/Gorica: A Sequence of Missed Geo-political and Geo-economic Opportunities
}

\author{
Igor J elen, Emst Steinicke, Kurt Sc harr
}

\begin{abstract}
The town was founded in a unique position, having the possibility during the centuries of taking advantage of a set of favourable circumstances. In the last century it developed in a particular way, being today difficult to be described following a twin city schema, or better that of a divided town, or of a multipolar pattern. Today the situation of the town may be considered stagnant, or even regressing, in any sense (politically and economically), giving the impression that the city as a whole is not capable of taking advantage of the geopolitics offered to it.
\end{abstract}

KEY WORDS Gorizia/Gorica, political geography, economic geography, Upper Adriatic/Eastern Alps, Italian/Slovenian borders

\section{Gorizia/Gorica - a particular case of a twin city ${ }^{1}$}

It is evident that, with the post-modern passage, and with the correlated change of paradigms, the most powerful spatial modelling factor - the attrition exerted by distance, namely by territory, on human activities and perception - has changed in its significance and impacts. This change is perceivable in any circumstance, and especially in territorial organization pattern, first of all in such phenomena as localization and distribution, organization and mobility, notwithstanding those of a planned or spontaneous character (Harvey 1997; Cairncross 1997).

This change exerts a particular influence on human settlement tendencies, interfering in redistribution and centralization processes, namely in the basic resulting distinction in accumulation centres and dispersion areas - in other words, in rural/urban schemas and in the formation of urbanization networks. The same goes for connected situations, defined and comprehended in more or less structured theories such as centre-periphery models, divided and twin-cities, and any theory representing any ideal town whenever proposed over time.

In a corresponding way, the geographical-urban method is comprehensibly losing capability: the spreading out of ICT, the disappearing (or the change, depending on interpretations) of political-territorial barriers, and the overcoming of a Fordist mode of organization - eventually applied on a definite regional schema - would coincide

Sociální studia / Social Studies 1/2017. Pp. 137-154. ISSN 1214-813X.

1 In order to render the text more fluid, the authors cite the toponyms in their official form, not considering local names and variants, even when original in this context; for a more detailed list of toponyms in this area see Steinicke, Jelen, Lieb, Löffler and Čede (2016). 
with the rise of a new concept of planning much closer indeed to "improvisation", or to a paradoxical "zero-time" planning, leaving us to imagine the necessity of elaborating a new urban epistemology (Brenner and Schmid 2015).

The Gorizia urban area - as represented today - presents an image that hardly can be considered as a spatial continuum, but possibly as a scattered set of centres, each of them tending to specialize in different historical epochs in specific functions. The result is an articulated space, evidencing a set of independent urban nuclei, each of them developing along an opposed axis; among them it is not easy to find a common feature or a basic identity. Such nuclei may be represented on a complex map, comprising Medieval Gorizia (at the castle foothill), the nineteenth century district (along the boulevard connecting the two railway stations), the Nova Gorica new town, the Šempeter/Vrtojba facility centre, and others depending on the scale assumed by the observer.

The most evident "twin city" aspect is represented by the development after World War II, evidencing the two sides - the "old" Italian Gorizia and the "new" Gorica (Nova Gorica) on the Slovenian side - reciprocally influencing, both functionally and aesthetically. Indeed, the actual Gorizia urban situation is the result of casual, not planned events, reverberating geo-political accidents occurring on a wider scale, inducing local sequences of structuration and re-structuration processes.

The more impactful of such changes coincide with the superposition of completely new political borders in the twentieth century that fractured the original organic unity, and, furthermore, with the post-modern transformation of the socialist new town on the Slovenian side into a paradoxical entertainment, leisure and casino city. In all this time, the different parts of the Gorizia/Gorica body seem not even have looked or needed a common framework - if we consider that only recently the authorities of the different municipalities began to draft a common urbanist design, taking the form of a EGTC (European Grouping of Territorial Cooperation), sponsored and promoted by European policies. ${ }^{2}$

The reality evidences that such spontaneous process are occurring in the framework of a "zero sum game" (intended as an urbanistic practice assuming the settled territory as a limited and not renewable resource, as it usually is), whereby the different sides are pursuing various development itineraries, hardly evidencing a common urban identity - which would be a characteristic of a twin city - namely the existence of a basic growth dynamic, with the different parts supposedly dialoguing or competing, or mutually informing and supporting each other (Buursink 1994; Ehlers 2001; Hansen 1983; Joenniemi and Sergunin 2011; Newman 2006; Schultz 2003, 2005; Debicki and Tamáska 2014). On the contrary, the different Gorizia/Gorica cores on both sides of the political border seem to run after each other, occasionally competing and eventually pursuing incompatible targets, never unifying in a coherent social and urbanist project.

The resulting map is a fragmented urban schema, distant from the usual modernist centreperiphery model, and something completely opposite to the organic and unilinear radial growth that is supposed to be characteristic of modern urban complexes from the beginning.

2 See Spagna (2003). 
It appears as something discontinuous, comprehending empty spaces and (almost) abandoned neighbourhoods; it is as well - for the same reasons - something flexible and adaptable, offering an intriguing combination of styles, of functional and aesthetic diversities, and furthermore a puzzle of ethnicities and cultures - stratified in the different stages of its history.

Indeed, more than a twin city - which supposedly derives from a characteristic urbanist formula, consisting in a set of reactions and feedback - it represents a complex of elements independently developing, just occasionally justifying and stimulating each other. In this article we intend to present this urban configuration, coupling it with both a particular evolutionary stage, with some geopolitical tension, the arising of a particular landscape, or some functional specialization.

In such a perspective, the evolution towards a bi-national organized European Grouping of Territorial Cooperation (EGTC) space is to be considered possibly already obsolete, since such city parts are today evolving in a new urban conglomerate, then merging in a unique undifferentiated "liquid" or "pulverized" pattern in the new spirit of globalization (Appadurai 1996; Bauman 2000).

As a result, nowadays the "greater Gorizia" schema is not a coherent container of functions and societies, but a multi-dimensional structure, consisting in a set of scattered centres connecting the parts of an environmentally and culturally diversified province. It appears today, paradoxically, it is necessary to represent the flexibility, namely the multi-functional structure, in order to face the current post-modern rapid evolutions - as already mentioned. But it is also a segmented city, extremely difficult to be organically managed.

This schema indeed is repurposing what was the role of Gorizia from the beginning, as a connection point among different and diversified regions, populations and economies, the east and the west, the north and the south of this portion of European continent, the mountain and the plain, peoples of different origins and cultures, productive rural areas with sophisticated urban elites.

Sometimes the town found itself in the middle of powerful waves of innovation, sometimes it has been the subject of a conservative reflux, skidding from a central position in a sleepy peripheral condition - as happened in

Figure 1: Görz/Gorizia in the year 1897

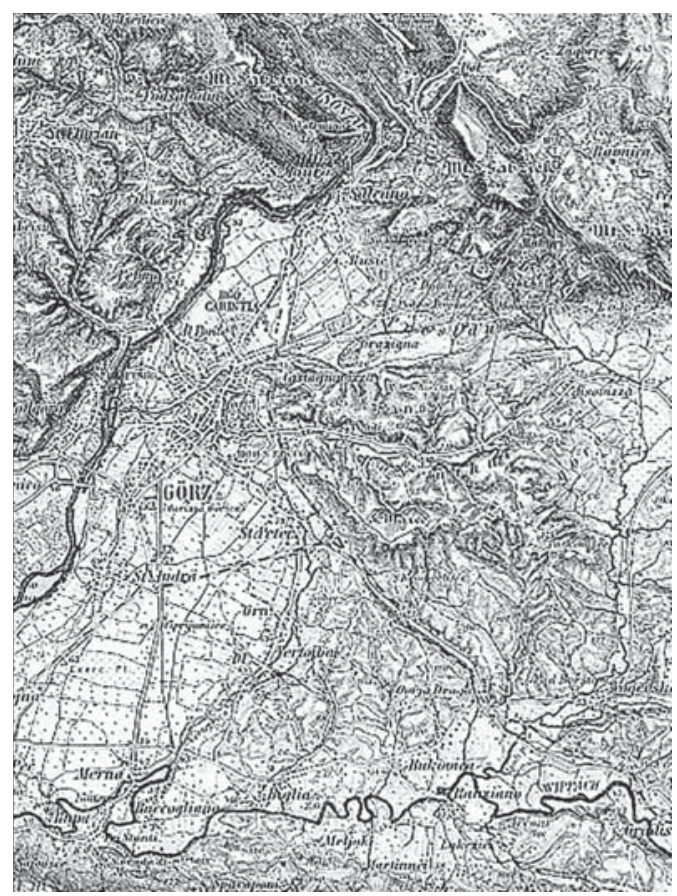

Source: Extract from the "Österreichische Spezialkarte" 1:75.000. no 5651 
the times of the consolidation of modern territorial states, when the border lost political sense, becoming just a militarystrategic instrument for the new states that accumulated power in a central capital city localized far away from the same borders.

\section{Position and urban setting: the starting point and the geo-historical stratification from the origin}

Gorizia/Gorica derived - from its mediaeval origin - from a definite geographical situation, capable of exerting its attraction on a wider area, in what could be defined as the European "isthmus", namely the crossing point - south of the Alps, close to the Mediterranean - between the Balkan and Italian peninsulas (and Western European countries). It has the typical role of connecting highly diversified regions, linking the continental hinterland with

Figure 2: Position of Nova Gorica with regard to the border between Italy and Yugoslavia in 1959

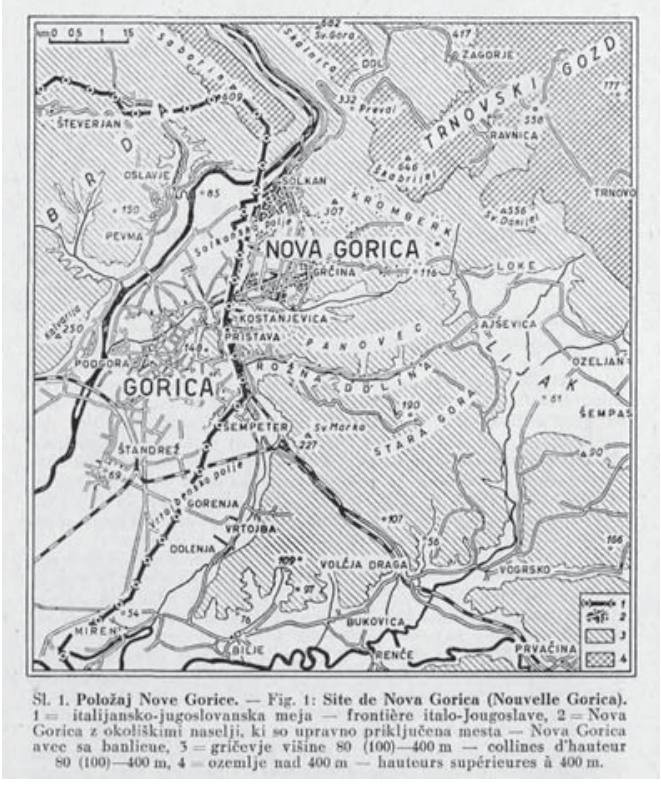

Source: Vrišer (1959: 46) the Adriatic coast, the arid Karst plateau and the Julian Alps with the piedmont arenaceous (marna, locally called "ponca") fruitful hills (Collio/Brda).

It means the first scent of the southern climate for those coming from the north, and the last Mediterranean place for those travelling in the opposite direction. It is the place where differentiated production may realize commercial success, in innovations and exchanges, in which the differences may transform into opportunities - or into conflicts, depending on the wider circumstances.

The city lies in a favourable position, on the middle course of the Isonzo/Soča River, typically localized in the foothills, with the mediaeval castle above that represented over the centuries the ideal checkpoint for local and long-range traffic. This position was the original motivation for the spontaneous formation of a commercial community settled below the castle (therefore "gorica" means "little mountain" in the mediaeval proto-Slovenian language) (Gasca Queirazza 1996).

Furthermore, such a location became the agglomeration point for further functions that superimposed and combined, from that time, the functions of political surveillance and territorial management (in feudal terms), symbolized by the castle and by the community of peasants, and later by merchants and artisans' networks spreading around it - under its defence, control or exploitation, depending on the circumstances.

It is the typical case of mediaeval "encellulement" (as defined by many geographers and the historian, Braudel [1979]; cf. Le Goff [2006]) at the confluence of the Isonzo/Soča valley 
in the wide fertile Friuli lowland, connecting latifunds organization (typical for the ample lowland region) and mountain independent cattle breeders and shepherds, then local production with long range transport and markets.

Such a situation may symbolize the synergy between commercial and strategic-political functions that is the premise for development of the successful urban history of the following centuries. It creates the premise for a rapid development of the town and of its ruling dynasty, the Counts of Gorizia, who were for centuries during the Middle Age the typical independent feudal authority, always in competition with other similar medieval powers (at first the Aquileia Patriarchate), but at the same time exerting on the local scale a territorialization effect.

The further course of history seems indeed not the result of deliberate decisions, but of both geopolitical accidents and periodic adaption to the circumstances. In the early centuries after $\mathrm{AD} 1000$, the Counts of Gorizia imposed themselves as the leaders of the wider province delineated in this transition area between the lowlands and the peaks, controlling the roads towards the continental interior.

Essential chronology:

1. The name of "Goritia" appeared for the first time in a donation of the Holy Roman Emperor Otto III in year 1001

2. Under the rule of the Counts of Gorizia, and of the Count Enrico II (1304-1323), Gorizia was granted the status of a town

3. In $\mathrm{AD} 1500$ the last Count of Gorizia, Lenhard, died without descendants, leaving the inheritance of the County to Emperor Maximilian von Habsburg

4. In the early decades of the seventeenth century, the Jesuits settled in Gorizia

5. 1713: Tolminotti or Tolminci uprising

6. 1837: the last French king, Charles X, was buried at Kostanievica Monastery, today in Nova Gorica

7. 1916: battle of Gorizia and occupation of the town by the Italian Army

8. 1929: the teaching of the Slovenian language was forbidden by the Fascist authority in Gorizia

9. Early 1950s: start of the build-up of new town Nova Gorica

10. 2004: admission of Slovenia into the EU, with the start of dismantling of border structures

Finally, when the Counts of Gorizia went extinct, the area fell under the rule of the Habsburgs - very famous for their astute matrimonial and inheritance strategies - that happened without war, indeed, just as an inheritance in $\mathrm{AD}$ 1500. In this period, however, Gorizia (together with the nearby Gradisca fortress) maintained its importance as a military border town. This was the era of the last significant wars between the Habsburgs and Venice - the most important of which, in the early 17th century (1615-1617, Guerra di Gradisca), finally established an equilibrium between the two powers, de facto introducing a period of decadence of the latter. Afterwards, with the stabilization of the frontier line, Gorizia rarely played a primary role in history, and its elite regressed to an ordinary provincial life, under the influence of outside powers (namely, in that period, the Habsburgs). 
Figure 3: The capital of Gorizia, an overal view

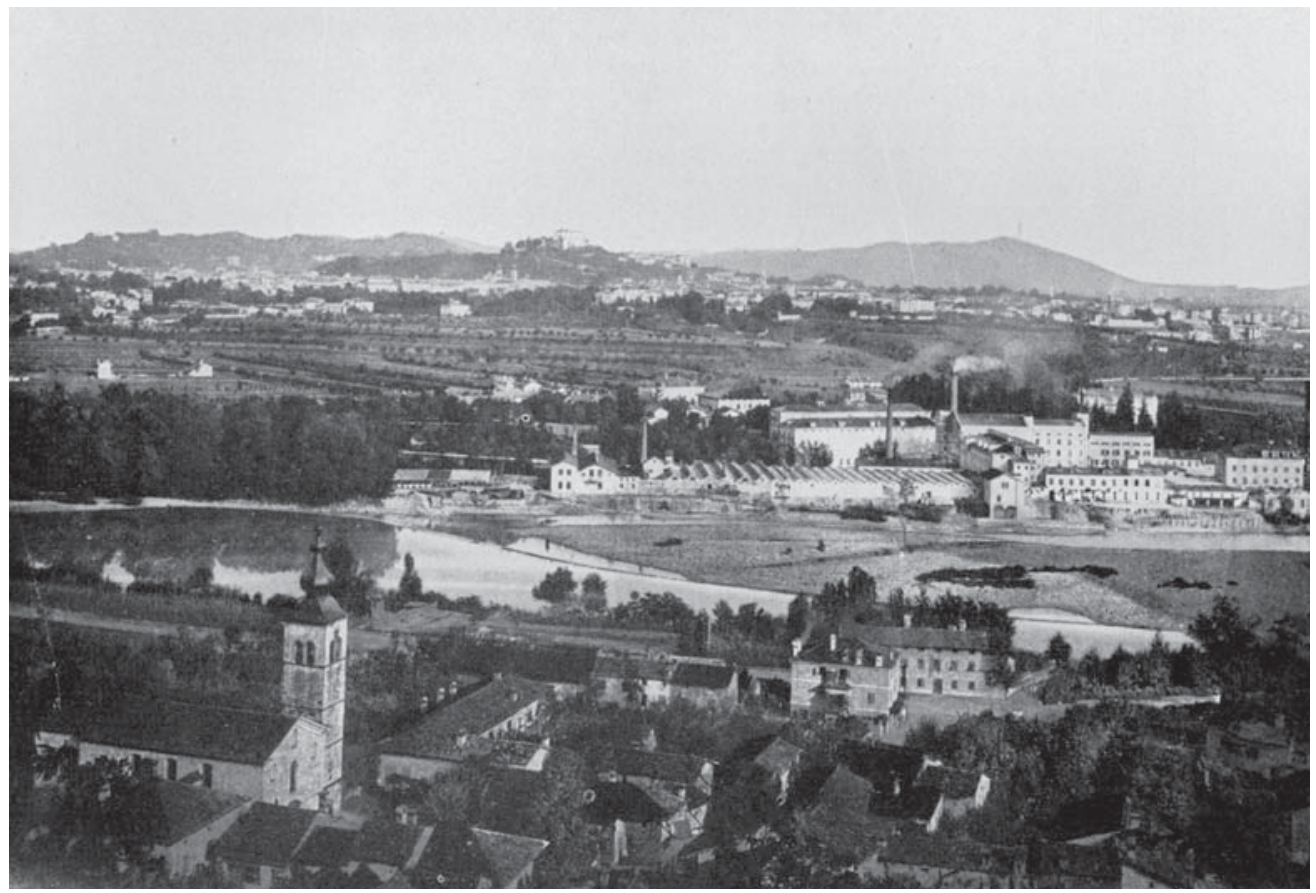

Source: Czoernig (1891: 298, 300)

Note: Alongside the right bank of the Isonzo River, south of the medieval city (with the castle in the background of the photograph), within the urban fringes of the former "Strazig-Podgora", an industrial complex built by the end of $19^{\text {th }}$ century, not far from the southern railway station. Within less than 80 years, the city of Görz developed as the most important industrial centre of the realm.

\section{From early modemity to World Warl}

In the new era, subsequent to the modernist evolution, the local-scale feudal frame has been overlaid by many other factors - as usual for this stage of political geography - and the same social-economic situation becomes increasingly complicated, with the affirmation of new players, both internal and external to the urban complex. This refers to the economic and commercial development that soon brought diversification of the social situation, with the consolidation of a monetary-capitalist circuit and the formation of new social strata (resident and itinerant artisans, merchant communities, brokers, bankers etc.). It is the case of the religious element and of the end of the Roman Catholic monopoly, with a sequence of innovations, finally converging in the Reform movement, and the consequent CounterReformation reaction (Ciceri 1969; Fabi 1991).

This era, in particular, proved to be an essential moment for the town, which in the early 17 th century caused significant change, the first one of a true modern character that assumes a predominantly ideological significance. In this period, Gorizia acquired the character of 
a monastery town, becoming the site of many confraternities and monastic orders that built up monasteries in the typical Baroque style that even today remains the prevalent architectonic attribute of the town.

Simultaneously, and consequently, the town lost its commercial attractiveness and vivacity, transforming it into a kind of conservative fortress. This happened to the advantage of nearby Trieste, which was growing much faster in the period of the rediscovery of maritime routes after the fall of the Venetian monopoly on the Adriatic, developing transport, industry and commerce, as well port and coastal functions.

Actually, the main preoccupation of Gorizia's ruling elite would become simply the efficient management of territorial resources, maintaining a conservative attitude, avoiding any possible shock to the local population (above all, after the news arriving of the Enlightenment and the French Revolution). This meant, in such a pre-industrial economic environment, the extension of more intensive control over the rural subaltern classes, which in the context of increasing latifundization led to the expropriation of both the rural Friulian communities of the plain and the Slavonic communities collocated mainly in the piedmont and mountain hinterland - and partially in the low Isonzo/Soča plain - based on communitarian autonomous rules and habits (Finzi, Magris and Miccoli 2002). Tensions occasionally rose, as was usual in those times of peasant rebellions throughout Central Europe, exploding finally in a general rebellion in the Tolminci uprising (Tolminotti) in $1713 .{ }^{3}$ But this bloody rebellion did not shake the ruling elite form its torpor.

With the passage of time, a further element emerged producing new ideologies, a new sense of belonging and new expectations, sometimes superimposed upon the pre-existing social schema. This is the ethnic-linguistic dimension, which acquired significance, often connected with a process of economic development and technological innovation. But, indeed, for a long time, until the end of the 19th century, social sentiment was not based on national identity, class belonging or secularist (anti-clerical) claims, or in other words on typically modern political elements. The original old town Italian (Romance) dialect-speaking elite coexisted with different groups - with the Latin-speaking clerics, with Austro-German bureaucrats (most recently immigrated from other parts of the Empire), with Slovenians and Friulians (always present in the city, but prevalent at the suburban fringes) - on the common ground of Catholic-Habsburg loyalty. But none of such ethnic elements, nor the many others that it is possible to identify in this time of changes, were characterized by a specific political significance or awareness (Fabi 1991; Finzi, Magris and Miccoli 2002).

The economy also experienced a certain diversification, with a human landscape that was further composed by garrisoned soldiers, middle rank clerics, friars from different religious orders, merchants, and itinerant artisans, transporting and making business with products from the colonies, arriving from the port of Trieste. This period of the life of Gorizia experienced some barely perceptible economic growth, maintaining the style of a quiet town

The eventual accumulation of central power at a different scale by the landlords at the expense of, and by expropriating, the peasant communities, was a general process, occurring all over Europe in different periods, being the basis for the formation of the absolutist modern state; such a process accelerated in the late mediaeval period. 
on the periphery of the empire; at the same time it had lost futher importance for strategic questions, due to its border position against Venice was no longer so important.

But at the same time, under Habsburg rule, the conditions of peace and stability set the stage for a further opportunity for innovation, for Gorizia to reinvent its role, inaugurating a new epoch - which with time became a non-secondary chapter of the "belle époque". So, starting at the end of the 18th century, the city slowly discovered that it was possible to define itself according to an "ante litteram" amenity function, which was implemented in the following century, after the construction of railways, as a prototypical recreation and tourist destination.

The Corso, the main street connecting the southern railway station with the Transalpina station, became a district of beautiful bourgeois villas expressing the different styles of the period (neo-gothic, neo-renaissance, eclectic etc.), designed by top famous architects, representing the status of the "belle époque" elite. As symbolic of this glory, the fact that the Bourbon dynasty chose the town to live in exile, and to be buried in the Kostanijevica monastery in the 19th century - a place, they were hoping, that would remain aloof from the troubles that were characterizing the European continent.

In fact, such a favourable condition - the remaining of Gorizia on the sidelines of the main course of history - soon proved to be a tremendous illusion. In reality, it became evident that the modern times would mean an acceleration of processes, both material and ideological, involving both centres and peripheries in structural transformation. So the town - not unlike many other border towns - became in the last decades of the 19th century a target and "incubator" of a sequence of tensions.

The changes triggered by the modernization process were so powerful that the wise but stagnant Habsburg bureaucratic state could not assimilate them; indeed, probably no institutions could mitigate such changes in a pluralistic and peaceful political game. They brought to maturation a sequence of asymmetries of new classes, of new social strata, and finally - as for any pluri-ethnic society - to the spreading out of a set of linguistic and ethnic identification markers, with climes of any kind that would soon contribute to the formation of a climate of tensions (Vecchiet 2003; Vrišer 1959).

Consequently, the contraposition took the form of anti-clericalism, of socialist classism, and of nationalism, inducing conflict between ethnicities and languages, conservatives and radicals, rich and poor, between rural and urban cultures and values, between industry and commerce against the archaic way of production, between religious conservatism and modern secularism. In such circumstances, suddenly cultural and social elements that had rarely in the past of the quiet multi-language Gorizia/Gorica played a significant role - namely the use of a idiom or of a dialect, the belonging to a religious community etc. - became a cause for life or death (Cattaruzza 2007). ${ }^{4}$

Finally, such contrapositions, recoded in different ways in the political arena, signified disaster, namely conflicts at all levels, inside and outside society, with any possible real or imaginary enemy: all these came together in the First World War, which signified for Gorizia

Actually, as far as we know, never in the local history had contrapositions been based exclusively on ethnic belonging, the use of different languages or similar identifying markers. 
the nightmare of finding itself, again, in a central geopolitical position, namely on the front line between the old Empire and the new growing nation-states - just one of the major contrapositions of a much wider conflict - and finally being conquered by the Italian army of General Cadorna in 1916.

The national "redemption" and the Italian conquest meant the recodification of names, toponyms etc.; the upset of an entire social strata; and the sudden disappearance of the ancient Imperial ruling class, with the outmigration of Austro-German notables and many members of the multinational entrepreneurial class, who had brought with them capabilities and capital (for details, see Finzi, Magris and Miccoli 2002; Ferrari 2002).

The etiquette of the Italian King (who would soon claim for himself the dignity of Emperor) took the place of that of the Kaiser, while the names of the irredentist heroes Mazzini and Garibaldi took the place of that of the Arciduca; the "Corso" was renamed "Italia" and "XX Settembre", and so on, for any trace and any element of the previous regime. This in a general effort to delete the memory, erasing a whole layer of names and symbols, filling the urban space with brand new icons, monuments, tables, inscriptions etc., in order to establish a new sense of belonging, of legitimizing what was in effect conquered by war and violence (for details see Fabi 1991).

This effort was just the preamble of a sequence of even more dramatic events, connected with the rise of totalitarian dictatorships, induced, possibly, in a cascade effect, by the same shocks provoked by WWI. Fascism manifested here, in this area, in the especially virulent form of the "fascismo di confine" (to some extent in continuity with 19th century nationalism), whose intention was not just the imposition of a new authority as elsewhere in Italy, but ethnic and cultural uniformity as well, eventually via assimilation, ethnic cleansing and violent instruments.

A programme, enunciated immediately after the war, that would soon trigger reactions at all levels, ${ }^{5}$ making more extreme any position: in fact, the new contraposition would overlay the pre-existent conflicts, developing on the pre-existent confrontation axis (mountain-plain, communitarian-individual, merchant-producer, modern-premodern, as well as North-South and West-East etc.), accentuating tensions and predisposing many to escalation.

The resistance movement of the Gorizia Slovenes - the only organized minority surviving - would become active in a few years, with the secret organization TIGR, ${ }^{6}$ which became rather quickly a militant organization (considered one of the first such type in all of Europe against the authoritarian new wave). The situation accelerated and escalated in the European climate of the time, soon bringing a new and even more destructive war, and then a sequence of revolutions, massacres and mass deportations - and that brought the whole of Europe to the brink of self-destruction.

5 As far we know, the first reunion of a new partisan movement in Nazi-occupied Europe, to be considered spontaneous even though supported by Cominform, took place in the nearby Trnovski gozd/Selva di Ternova in January 1941 (oral source testimonial by Karlo Ferletič, Doberdò del Lago/Doberdob).

6 Acronym of Trst-Istra-Gorica-Reka, the cities on the Upper Adriatic claimed by Slovenian irredentists. 
In Gorizia, World War II ended with the invasion of Tito's partisan army, seeking revenge for twenty years of fascist anti-Slovene humiliation, and finally with the exodus following the ceding of territories lost by Italy to the new socialist Yugoslavia, including the main provincial hinterland of Gorizia (for details, see Ravnikar 1984; Vrišer 1959): as it is commonly said, the war was "very long" in this area, degenerating into systematic and mass reprisals and acts of revenge, continuing even after the official end of the war and the Nazi-Fascist defeat. Finally, a new contraposition scenario evolved, in which the previous friends suddenly became new foes, with the consequence of cleavages, political betrayals and moral tragedies on all sides.

This situation is visualized by the final event of the city's division, politically and symbolically repurposing the world's division into two blocks, within the context of the nightmare of nuclear destruction. Thus, with the superimposition of the new border, Gorizia/Gorica found itself again on the front line, representing possibly the first post-war divided town.

\section{Rec onstruction, the socialist city, and "mild" socialism}

Anyway, even considering these tensions, the post-war stabilization saw a new period of growth: in this period Gorizia/Gorica experienced a sequence of changes that brought a new scenario, on the one side, of rapid recovery from the destruction and the growth of a free market, western-style economy. On the other side, the rise of a new society based on the principles of Yugoslavian socialism that, after a period of rather cruel political pressure (not much different from the Stalinist style of government elsewhere in the 1950s), stabilized into a more moderate pattern, avoiding extreme collectivization programmes, maintaining some border openness and even some economic freedom at the level of small firms - especially in agriculture, commerce, tourist and artisanal activities (authors' recorded interview archive; Jelen 2010).

The border partition began to represent a kind of mirror in which both sides - capitalist and socialist, free and planned, democratic and popular - were continuously confronting and representing for the other side, a symbol (and eventually a negative benchmark, "what we don't want to be"). Possibly this was the occasion for Gorizia/Gorica to develop a true twin city structure - but such evolution indeed lasted probably not long enough. Even more important, more than the functional and material aspects, the division concerned cultural and human aspects, meaning the separation of families, social networks and organizations of all kinds (Medved and Velušček 2002, 2004).

And this also took place at a regional scale: in fact, the separation meant, for the Yugoslavian side, the cutting off of the main urban centre from its surrounding area, the administrative city quarters from the rural area that usually covered the entire space of the Vipacco/Vipava and Isonzo/Soča valleys, the Karst and Brda/Collio regions that traditionally represented the Christallerian tributary area of the downtown. This fact - the sudden separation of the city from its hinterland - signified, for the city, a loss of importance and of functional attraction, and, for the hinterland, a loss in terms of functional and economic capability, to say nothing about the human consequences of such a division. 
Finally, the post-war division brought the formation of a new spatial setting with, on the Italian side, the old town market district marginalized and insulated, being cut off from its surrounding area; and, in a complementary way, on the Yugoslavian (Slovenian) side, the rise of a relatively wide rural area without any urban functional reference (hospital, schools, transport infrastructure, administration etc.) (Finzi, Magris and Miccoli 2002).

In such circumstances a vacuum developed on the eastern side, prefiguring the necessity (or the possibility) of elaborating what the current urban geography handbooks define as a new town, indeed in those circumstances, a socialist city. In fact, the new Yugoslavian ruling elite took the opportunity to plan and build up something new - not just a new urban structure, but a new society and a new economy as well - pursuing the dictates of socialist ideology, and transplanting them on an urbanist new order. The new town is a visible example of the new way of organizing the territory, much more efficient and modern that the "old fashioned" capitalist approach: it meant the construction of a new city near the older one (instead of destroying the latter, as usual in similar situations), in order to offer an example of the capability of the new ideology.

The socialist elite wanted to demonstrate that the new system was able to build a new city, representing and applying the best of modernist architecture. The structural elements and the general planning were based on the search for symmetries, applying criteria of rational zoning and linear organization - an operation rather easy to realize in this case, since it assumed an empty rural space.

Nova Gorica - as in other planned socialist cities - evidences a new city design expressed by, amongst other things, the dominance of higher, bigger and larger structures characterized by a functional orientation without taking old property lines into consideration. This refers to buildings, squares, streets, neighbourhoods and infrastructure, public facilities and surveillance centres. Indeed, given its small dimensions, Nova Gorica does not show all classical elements of the socialist city clearly (e.g. heavy industry, standardized construction methods, "gentrified" city quarters for the "nomenclatura" and social housing hruščovkastyle in the periphery, and widespread distribution of the "dača" phenomenon) (Bähr and Jürgens 2005; Brunn, Williams and Zelger 2003; Hofmeister 1996; Jelen 2009).

Furthermore, in combination with such criteria, the urban space was decorated with rows of statues representing "diverzanti" and saborators, partisans and proletarian heroes, with the intention of making of this space a permanent gallery of the communist ideal and of resistance to Nazi-fascism, predisposing the masses to embrace the legitimization of the new socialist deal. An updated version of the ideal city, namely the eternal dream of urbanists and politicians, even at a provincial scale, to be put in comparison with the decadent and bourgeois example offered by the old Gorizia on the other side.

In fact, Gorizia - similarly to Trieste, which was suffering from the same circumstances in that period - was one of the few cities on this side of Italy not enjoying the economic "miracle" in the early 1960s in Western European countries. At this time, the East-West contraposition as mentioned above, well represented locally by Gorizia's division - was perceived as definitive in the context of a long-term messianic confrontation between the decadent capitalist society and the socialist project. Indeed, the reality of this period, from post-war to system change in the late 1980s, stabilized in a rather unpredictable manner. The border maintained a high permeability, 
and communist rule in Yugoslavia adapted to take much more mild forms, in contrast to the other countries of the Eastern bloc, opening its borders to receive tourists and for economic migration (with Yugoslavian workers enjoying the possibility of migrating internationally), and for local trans-frontier traffic.

Small and domestic activities survived collectivization in many sectors, and this, paradoxically, while the official economy began rather quickly to show signs of decadence, experiencing a kind of mixed Balkan-central European milder communist variant, with the spread of local corruption and of the "grey economy" - which was to some extent a kind of resistance to centralization that with time would provoke a severe accumulation of inefficiencies, leading finally to a system crisis. This also, considering that the economic inefficiencies were combined increasingly with (and sometimes provoked by) a generic anti-system popular attitude. In this sense, the system's adaptation and the failure of the socialist programme may signify a new social consciousness, anticipating and predisposing the population to a transition - a transition that in any case would not be "soft", considering the tremendous wars during the 1990s in the rest of Yugoslavia.
Figure 4: Land use, building functions and network of trade and handcraft activitiies in Nova Gorica

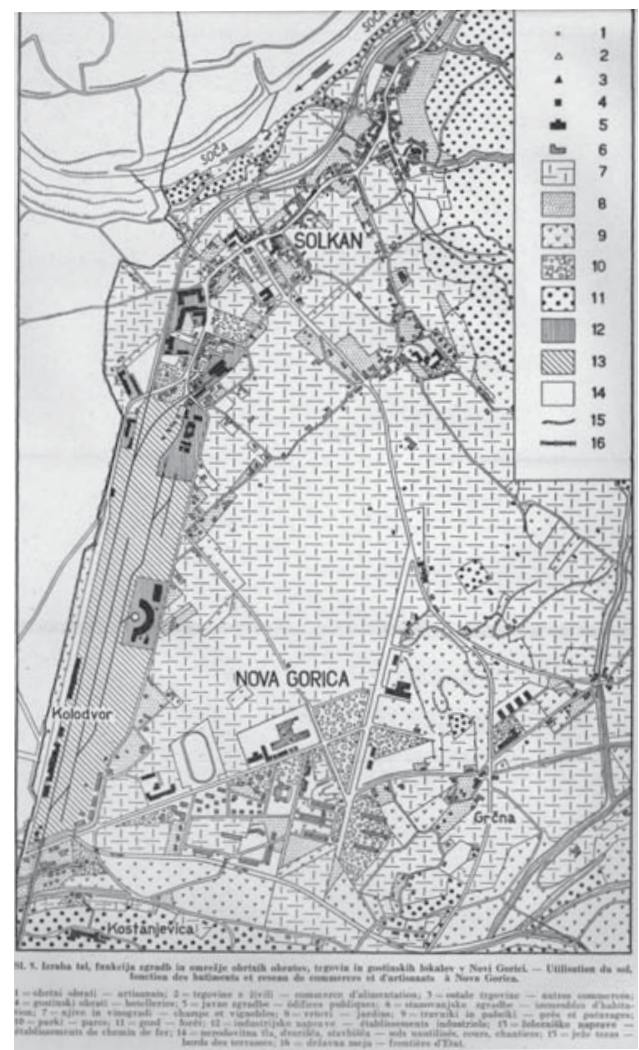

Source: Vrišer (1959: 73)

\section{The transition to post-modemity and the new development}

Tito's Yugoslavia acquired a certain role in international politics, disengaging from the USSR monopoly and promoting a "third way" with the movement of non-aligned countries, proudly claiming legitimization due to the maintaining of independence from superpower hegemony. Indeed, the destiny of socialist Yugoslavia became evident rather quickly, and just after completion of the construction project, structures and ideologies - exhibited through the new urban scenario showed signs of a premature ageing, finally transforming into a kind of - as it has been defined "carrozzone" (circus), unable to govern effectively. In this context, showing a pragmatic attitude, the socialist local authority adapted to the circumstances, elaborating a transborder economic model, using the weakness of the old Gorizia, which at the same time was suffering from marginalization, similar to that of Trieste, and the exclusion from its main hinterland. 
In fact, the "late socialist" Nova (New) Gorica economy became - to some extent parasitical, opportunistically taking advantage of the differences in terms of wages and prices (derived mainly from the periodical devaluation of the YU Dinar compared to the already weak Italian Lira), paradoxically adapting its economy to transborder tourism, entertainment, commuting and shopping, and de facto dumping gasoline, raw materials, agro-food-meat prices and other typically capitalist commodities.

Finally, the political system changed from the Yugoslavian confederation to sovereign Slovenia, fortunately in a rather pacific way, setting the stage for further transformations. In the first period following independence, the new Slovenian government continued to develop the opportunities of its border position (namely favourable prices, and tax and cost differences for a set of products and services). There was also a wider development of trans-frontier commerce, of commuting shopping and tourist activities, and, in particular, a boom in the gambling industry, based opportunistically on a prohibitionist law in Italy that incentivized masses of gamblers from the rich north-eastern Italian provinces to come to the Nova Gorica casinos. This period, during the YU-SLO transition, was characterized by the difficult challenge of shifting from a centralized, planned economy to a free market, to a pluralist system and a state of law.

Any period in which an economy experiences a stage of wild liberalism - the transition to a higher and more mature stage of a free but regulated economy - cannot occur without tensions. In post-socialist Slovenia, this meant financial speculation, confusion in state and social organization, consumption of soil and resources, and financial and consumerist/commercial bubbles, with the kind of booming financial services and real estate markets that tend to characterize the early period of any capitalist development. A visible example demonstrating this situation is the grave of Carlo Michelstaedter (1887-1910, Gorizia's Jewish-Italian writer, philosopher, artist and man of letters) in the Hebrew cemetery, which remained on the Yugoslavian side after WWII, and was disturbed and disfigured disrespectfully by the construction of a highway in socialist times, and which in "democratic" times was adapted as a slot machine parlour in the cemetery chapel.

Eventually, Slovenia had the chance to develop profitable as well as innovative high valueadded and cultural capital-based activities (that to some extent coincide with a return to a preindustrial and pre-modern economic stage). It is possible to mention among them, leisure, nature-based and sports tourism (in the Soča upper valley), entertainment and thermal/ bath tourism, cultural and educational activities (ethnographic museums network), as well as eco-, fruit- and gastronomic agro-tourism (especially incentivizing the Brda and Kras environmental resources). In essence, the transition for the Slovenian side of Gorizia was characterized by a difficult transition from the rude exploitation of a rent position (and a lowcost economy parasitizing the Italian neighbours) to the development of innovative activities (high value tourism and quality agriculture). ${ }^{7}$

Paradoxically, small domestic and rural economies, and even a certain local-scale entrepreneurial culture, survived in socialist times, which was actually a defence against the central state, and may now represent the starting point for new development activity. 


\section{Old Gonizia stagnation and the complementary New Gorica development cycle}

This evolution happened in direct relation with, and in a complementary manner to, the negative economic trajectory of the "old" Gorizia that started to be evident just after the collapse of communism. This took place in a paradoxical manner, since the transition from socialism theoretically should have given an advantage to the western side of Gorizia, which could potentially have benefited from the post-socialist transition due to the differential of efficiency between the free market and destructuration of the centrally planned economy (as indeed happened in other similar circumstances).

On the contrary, the immediate start-up of the post-communist economy benefited from the "obsolescence" of the Western Gorizia side - in terms of public debts, of taxes, of administrative procedures, and over-bureaucratization, which had provoked as a consequence, in the meanwhile, the overall increase in costs and prices (as typical effects of the so-called end-of-democracy-cycle, with the accumulation of many inefficiencies). Thus, at the end of the transition, Italian Gorizia proved to be unable to face the competitive attraction of post-Yugoslavian Gorica, a fact that would soon lead to the further decline of the Italian side which has lasted until today, eventually combining with the "global crisis" started in 2008.

Finally this (still actual) crisis has also affected a significant portion of the Slovenian post-socialist economy, making evident that the economy cannot be based exclusively on transborder relations, on "bencinski turizm" (or "petrol tourism", as the press usually refers to it, in journalistic jargon), or the dumping of dentist services (by attracting clients with artificially low prices).

Paradoxically, the Slovenian economy rather quickly found itself burdened by public debt and a financial-bank crisis that resembled the short-lived socialist bankrupting of Yugoslavia, if we consider that Slovenia, after just 25 years of independence and democracy, already has a public debt-to-GDP ratio of about $80 \%$. The ongoing crisis is also affecting the "sparkling" casino-hotels along Titova cesta, Nova Gorica's main street that may have to re-think their business model.

\section{Conclusions: A sequence of missed opportunities}

In each historical epoch we observed a particular use of the territory and construction technologies, land use patterns, landscape management, social organization, and governance methods. The changing circumstances induced, and respectively have been induced by, a sequence of transformations, sometimes unexpected, sometime just barely perceivable about which the population was not aware - that reverberate on the town's organization, involving new areas, provoking changes inside the city and in the relations between the centres and periphery. The case of Gorizia/Gorica evidences that transformations do not necessarily correspond to a change in identity patterns.

The different sides of the town never represent a mirror for each other - as many suppose is natural for twin cities. Rather, each side pursued a development strategy independently from the neighbouring side, eventually making a profit off the other's difficulties. Probably 
because of this, the Gorizia/Gorica urban complex has never recovered (and has probably definitively lost) the identity it had developed during the "golden age" of the "belle époque". The various parts of the city do not consider the possibility of a true win-win scenario; on the contrary, they often pursue purely competitive (and fundamentally self lesionist) strategies. This narrow-minded attitude impedes the well-functioning of the town community, repeatedly evidencing the incapacity to comprehend what, in a certain period, is the true innovative and driving element, and consequently the self-elaboration and coherent realization of a certain goal at the different levels - such as optimal land use management, social improvement, and technological innovation.

The result is that today the older side is simply empting, both functionally and demographically, and the new one is slipping into a crisis that is the typical result of a short term strategy of pursuing internecine competition. The oldest and most beautiful "fin de siècle" villas and aristocratic palaces of Gorizia are sadly hanging up signs with the inscription "in vendita" ("for sale"), while the new Gorica socialist structures appear decadent and run-down. In fact, the new Gorica is running after the old one, and the current crisis (including a real estate crisis, financial and consumerist bubbles, declining attractiveness of the gambling industry and of parasitic commuting, and in speculative trade) demonstrates the immaturity of its development pattern. The last chapter at least for the western side - is that of the asylum seekers moving into the town but who are not actually filling the vacuum left by the stagnation; on the contrary, they seem to multiplying the crisis effects. The centuries of Gorizia's evolution shows the risk ultimately unavoidable - that human systems will suddenly find themselves in a kind of "cul de sac" of political geography that cannot in principle be managed with the instruments of good governance. Gorizia's communities have demonstrated themselves to be unable to cooperate, and this means they risk not being able to understand what is going to be the next change, and the next opportunity, instead simply suffering in a subaltern manner through any transformation that may occur at a wider scale.

Finally, it is possible to define the history of Gorizia/Gorica, as well of many other places, as a history of missed opportunities, a fact mainly due to the lack of affirmation of a true civil society, both culturally and economically (and ultimately trans-border

Figure 5: Cover of the "Review Rassegna Tecnica del Friuli Venezia Giulia" (3/2003), the year Slovenia entered the European Union, with map of the "Greater Gorizia" area

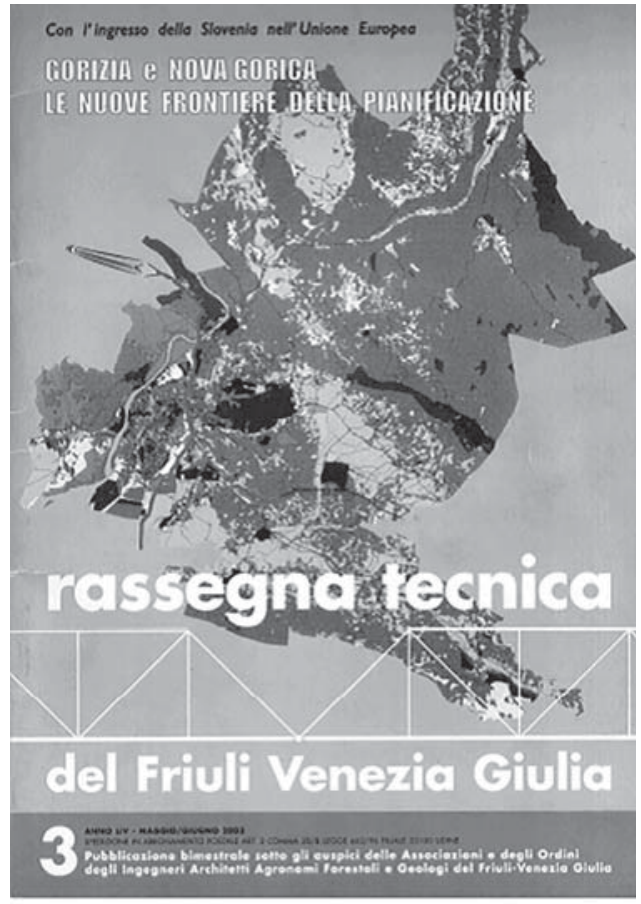


or trans-national), as it was in the past, capable of realizing the opportunities that geopolitics makes possible and offers periodically to the town.

Indeed, both the leading elites and emerging classes were periodically enchanted by ideological alternatives - instead of thinking about questions of good governance. Then, after some "revolution" having taken the power and pursued its revenges, the settlement soon transforming into a rent position, administering parasitically that same power. In the different epochs we may list among such ruling elites the obedient clerics, empire-disciplined bureaucrats, Risorgimento nationalists, real estate speculators, socialist idealists, and possibly today the "nostalgia" practitioners, who indeed seem to manifest the same pretextual attitude within the same repeating scenario.

\section{References}

APIH, Elio. 1966. Italia, Fascismo e Antifascismo nella Venezia Giulia (1918-1943). Bari: Laterza.

APPADURAI, Arjun. 1996. Modernity at Large: Cultural Dimensions of Globalization. Minneapolis: University of Minnesota Press.

BÄHR, Jürgen and Ulrich JÜRGENS. 2005. Stadtgeographie II. Regionale Stadtgeographie. Das Geographische Seminar. Braunschweig: Westermann-Verlag.

BAUMAN, Zygmunt. 2000. Liquid Modernity. Cambridge: Polity Press.

BRAUDEL, Fernand. 1979. Civilisation matérielle, économie et capitalisme, XVe-XVIIIe siècle. Paris: Armand Colin.

BRENNER, Neil and Christian SCHMID. 2015. "Towards a New Epistemology of the Urban?" City 19 (2-3): 151-182.

BRUNN, Stanley D., Jack F. WILLIAMS and Donald J. ZEIGLER, eds. 2003. Cities of the World. Lanham: Rowman \& Littlefield.

BUURSINK, Jan. 1994. “Dubbelsteden?” [Double towns]. Acta Geographica Lovaniensia 34: 175-180.

CAIRNCROSS, Frances. 1997. Death of Distance: How the Communications Revolution Is Changing Our Lives. Boston: Harvard Business School Press.

CATTARUZZA, Marina. 2007. L'Italia e il confine orientale. Bologna: Il Mulino.

CHRISTALLER, Walter. 1933. Die zentralen Orte in Süddeutschland. Jena: Gustav Fischer.

CICERI, Luigi, ed. 1969. Guriza. Udine: Società filologica friulana.

CZOERNIG, Karl. 1873. Görz, Oesterreich's Nizza: nebst einer Darstellung des Landes Görz und Gradisca. Vienna: Wilhelm Braumüller.

CZOERNIG, Jr., Karl. 1891. "Forstwirthschaft, Jagd, Industrie, Handel, Gewerbe und Verkehr in Görz und Gradiska.” Pp. 295-302 in Die österreichisch-ungarische Monarchie in Wort und Bild, Küstenland. Vienna: K.k. Hof- und Staatsdruckerei.

DĘBICKI, Marcin and Máté TAMÁSKA. 2014. "Laboratories of Integration: Divided Twin Towns at River Borders in the Visegrad Countries and Germany." Socio.hu. Social Science Review. Special Visegrad issue 2: 1-20. Retrieved September 9, 2017 (http://www.socio.hu/uploads/files/Visegrad/1debicki_ tamaska.pdf).

EHLERS, Nicole. 2001. "The Utopia of the binational Cities." GeoJournal 54(1): 21-32.

FABI, Lucio. 1991. Storia di Gorizia. Padua: Il Poligrafo.

FERRARI, Liliana. 2002. "Gorizia ottocentesca, fallimento del progetto della Nizza austriaca." Pp. 313-375 in Il Friuli-Venezia Giulia, della serie Storia d'Italia, le Regioni dall'unità a oggi, edited by Roberto FINZI, Claudio MAGRIS and Giovanni MICCOLI. Torino: Einaudi. 
FINZI, Roberto, Claudio MAGRIS and Giovanni MICCOLI, eds. 2002. Il Friuli-Venezia Giulia, della serie Storia d'Italia, le Regioni dall'unità a oggi. Torino: Einaudi.

Franziszeischer Kataster, Katastralgemeinde (Nr. 86). Görz mit der Enclave Prestau im Küstenlande, 1822 mit Nachträgen von 1894 (Blatt 1). Retrieved September 20, 2017 (http://www.geog.ucsb.edu/ mapsandsociety/slides/historical_maps/index.html).

GASCA QUEIRAZZA, Giuliano et al. 1996. Dizionario di toponomastica. Storia e significato dei nomi geografici italiani. Milan: Garzanti.

GRUSOVIN, Marco (ed.). 2007. Cultura ebraica nel Goriziano. Udine-Gorizia: Forum.

HANSEN, Niles. 1983. "International Cooperation in Border Regions: An Overview and Research Agenda." International Regional Science Review 8: 255-270.

HARVEY, David. 1997. La crisi della modernità. Milan: Il Saggiatore.

HELLER, Wilfried, ed. 2011. Identitäten und Imaginationen der Bevölkerung in Grenzräumen. Ostmittel- und Südosteuropa im Spannungsfeld von Regionalismus, Zentralismus, europäischem Integrationsprozess und Globalisierung. Berlin: LIT Verlag.

HOFMEISTER, Burkhard. 1996. Die Stadtstruktur: ihre Ausprägungen in den verschiedenen Kulturräumen der Erde. Darmstadt: Wissenschaftliche Buchgesellschaft.

JELEN, Igor. 2009. "Modelli di città sovietiche e post-sovietiche in Asia Centrale: una rassegna." Pp. 213-247 in Da Berlino a Samarcanda. Città in transizione, edited by Marzia MARCHI and Carla TONINI, Roma: Carocci, Università Bologna: Quaderni Dipartimento di Discipline Storiche.

JELEN, Igor. 2010. "The Valley of the Three Frontiers in the Mountains of the North Friuli: Identity and Structural Processes in the Passage from Traditional to Global Society." Pp. 77-93 in Grenzverkehrungen, edited by Werner WINTERSTEINER, Georg GOMBOS and Daniela GRONOLD. Klagenfurt: Wieserverlag.

JOENNIEMI, Pertti and Alexander SERGUNIN. 2011. "Another Face of Integration: City Twinning in Europe." Research Journal of International Studies 22: 120-131.

LE GOFF, Jacques. 2006. Il Medioevo. Alle origini dell'identità europea. Bari: Laterza.

MEDVED, Anja and Nadja VELUŠČEK. 2002. "Moja meja.” [My border]. Short film, prod. Kinoatelje Gorizia/ Nova Gorica.

MEDVED, Anja and Nadja VELUŠČEK. 2004. "Mesto na travniku." [The town on the meadow]. Short film, prod. Kinoatelje Gorizia/ Nova Gorica.

MORELLI DI SCHÖNFELD, Carlo. 1855. Istoria della Contea di Gorizia. Vol. I. Gorizia: Premiata Tipografia Paternolli.

NAZZI, Gianni. 1993. Defriulanizzazione di Gorizia. Gorizia: Clape Cultural Aquilee.

NEWMAN, David. 2006. "The Lines that Continue to Separate Us: Borders in our 'Borderless' World." Progress in Human Geography 30(2): 143-161.

PILLON, Lucia, Emanuela UCCELLO and Sergio ZILLI. 2000. Gorizia e dintorni. Gorizia: Libreria Editrice Goriziana.

RAVNIKAR, Edvard. 1984. "Nova Gorica po 35 letih.” [Nova Gorica after 35 years]. Arhitektov bilten 68-69: 43-46.

SCHULTZ, Helga. 2003. Twin Towns on Border as Laboratories of European Integration. Frankfurter Institut für Transformationstuiden, Abrbeitsberichte, 4/02, Frankfurt (Oder). Retrieved September 9, 2017 (https://www.europa-uni.de/de/forschung/institut/institut_fit/publikationen/discussion_ papers/2002/04-02-Schultz.pdf).

SCHULTZ, Helga. 2005. Stadt - Grenze - Fluss: Europäische Doppelstädte. Berlin: Berliner Wissenschafts-Verlag.

SPAGNA, Enzo. 2003. “Gorizia, Nova Gorica e Šempeter-Vrtojba. Le nuove frontiere della pianificazione.” Rassegna tecnica del Friuli Venezia Giulia 3: 10-16. 
STATISTISCHEN ZENTRALKOMMISSION. 1918. Spezialortsrepertorium der Österreichischen Länder. Spezialortsrepertorium für das Österreichisch-Illyrische Küstenland. Bearbeitet auf Grund derErgebnisse der Volkszählung vom 31. Dezember 1910. Vienna: Verlag derDeutschösterreichischen Staatsdruckerei.

STEINICKE, Ernst, Igor JELEN, Gerhard Karl LIEB, Roland LÖFFLER and Peter ČEDE. 2016. "Slovenes in Italy: A Fragmented Minority." European Countryside 8(1): 49-66.

STURMAR, Barbara. 2010. Gorizia Nascosta, raccolta illustrata di curiosità di Gorizia e della sua provincial. Trieste: Lint Editoriale.

TAVANO, Luigi. 2004. La diocesi di Gorizia, 1750-1947. Mariano del Friuli: Edizioni della Laguna.

VALENTINČIČ, Dejan. 2017. "The integration process of non-Slovenian ethnic population in the Municipality Nova Gorica in the context of wider Slovenian society". Doctoral dissertation. Nova Gorica: School of Advanced Social Studies.

VECCHIET, Romano. 2003. "Direttrici di traffico ferroviario al confine orientale". Pp. 209-248 in Enos COSTANTINI (ed.), Slovenia, un vicino da scoprire. Udine: Società Filologica Friulana.

VRIŠER, Igor. 1959. "Nastanek in razvoj Nove Gorice: geografija novo nastajajočega mesta." Geografski vestnik 31: 45-78.

\section{Authors}

Igor Jelen is Associate Professor in economic and political geography at University Trieste, Italy. Since the 1990's he spent much time in Central Asia, where he carried fieldwork and investigating transition processes of those post-Soviet systems. Beside this, his favourite research work concerns the Eastern Alpine - Upper Adriatic geography, with particular concern to trans-frontier and European integration issues, minorities, cultural and economic processes, in the context of postmodern - globalization passage.

Contact: igor.jelen@dispes.units.it

Kurt Scharr studied history and geography, since 2016 full professor (Austrian History) at Innsbruck University, Austria. He is specialized on late 18th, 19th century of Habsburg monarchy. His territorial focus is on the Alpine regions as well as on the Carpathians. The main area of research is Bucovina, Transsilvania and historical Tyrol. Thematically he works currently on the Franciscean Cadastre and on the Greek-Oriental Religious Fund of the Bucovina.

Contact: Kurt.Scharr@uibk.ac.at

Ernst Steinicke, is Professor at the Department of Geography at the GEO Faculty of the University of Innsbruck, Austria, and director of Innsbruck's research group "Demographic Change in the Alps" (DCA). He specializes in Social and Population Geography as well as in Regional Geography; his research foci include studies of ethnic minorities, counterurbanization, amenity migration, and demographic change. His study areas are the Alps, the U. S. Sierra Nevada, Marocco's Atlas range, the Western Caucasus, Mt. Kenya and Uganda's Rwenzori mountains.

Contact: Ernst.Steinicke@uibk.ac.at 